\title{
ПРОБЛЕМЫ БЕЗОПАСНОСТИ ДЛЯ БУДУЩЕГО СЕРБИИ
}

\begin{abstract}
Аннотация
Основной проблемой анализа в работе является возникновение лжегосударства Republika e Kosovës и действия ключевых субъектов международных отношений, направленные на его признание. Речь о таких, как НАТО и ведущие члены ЕС. Их насилие стало возможным в специфических условиях господства силы над правом и справедливостью. Цель работы - научное описание содержания и методов действий внешних факторов по созданию и построению лжегосударства Republika e Kosovës, а также по его признанию. В то же время представлены факты, которые аргументированно показывают, что это противоречит международному праву.

После осуществления анализа центр тяжести переносится на вопрос обоснования важности Косова и Метохии для будущего сербского народа и Республики Сербии. Вопрос Косова и Метохии был и остается серьезной проблемой безопасности, поскольку от его решения во многом зависит сохранение духовной силы и общего будущего Сербии и сербского народа. Изложенные факты подводят к выводу, что, несмотря на текущие проблемы, трудности, давление и навязывание ложных обещаний, Сербия должна оставаться твердой, решительной и стойкой в защите территориальной целостности, неприкосновенности и национального единства; должна посредством переговоров находить адекватное решение. А поскольку ни Запад, ни сепаратистские власти в КосМете не настроены находить адекватное решение в соответствии с международным правом и Конституцией Республики Сербии, необходимо ждать наступления лучших времен, поскольку право, справедливость и тенденции изменений в международных отношениях — на стороне Сербии.
\end{abstract}

Ключевые слова: лжегосударство Косово, Republika e Kosovës, вызов безопасности, Сербия, НАТО, Брюссельский договор, национальные интересы, сербский народ.

DOI: $10.51180 / R P S .2021 .18 .1 .003$

\section{Автор}

\section{Митар Ковач}

профессор, генерал-майор в отставке, учредитель и директор Евразийского форума по безопасности (Белград, Сербия)

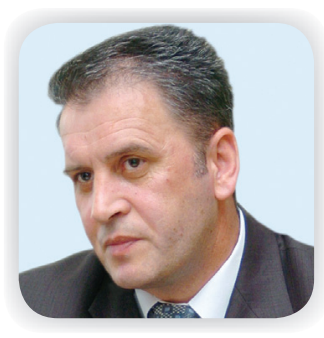

\section{Введение}

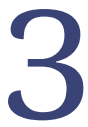
апад торопится, чтобы как можно скорее принять т.н. Постоянное обязывающее соглашение, которое узаконит ложное государство Republika e Kosovës, существенно переместит международно признанную границу Сербии с Кошаре на Мердаре. Таким образом, будут косвенно оправданы все те разорительные последствия натовской агрессии 1999 года на СР Югославию, осуществленной вопреки нормам международного права. Изначально стратегическая цель США заключалась в том, чтобы путем применения насилия создать ложное НАТО-государство на юго-востоке Европы. Впоследствии, в 2008 году, была проведена Всемирная кампания, призванная признать это творение. Все проводилось поэтапно по сценарию США с участием НАТО, а затем и ЕС.

Альянс по-прежнему работает над поиском путей углубления политического, экономического и оборонного 
сотрудничества с Сербией, дабы найти модель признания лжегосударства Republika e Kosovës в международных учреждениях и в конечном счете в $\mathrm{OOH}$ и НАТО. Однако в народе, в первую очередь из-за агрессии 1999 года, нет поддержки в вопросе налаживания тесного сотрудничества с США и НАТО. Годы и продолжение стратегии легализации оккупации и провозглашения ложного государства Republika e Kosovës показали, что силы Запада однозначно встали на сторону албанского фактора в Косово и Метохии; в Боснии и Герцеговине отчаянно пытаются подавлять каждый атрибут государственности Республики Сербской, поддерживая тенденции к унитаризации БиГ под прикрытием проведения политики европейской или евроатлантической интеграции. Но жизненно важные национальные интересы сербского народа в Сербии, Черногории и Республике Сербской поставлены под угрозу именно теми государствами, которые руководят процессами интеграции.

Применяемые стратегии в США реализуются как старой, так и новой администрацией, часто на основе личных оценок и инерции, то есть на базе «старой матрицы» действий, которая игнорирует новую геополитическую реальность многополярного мира. Поэтому мир с каждым днем становится все более нестабильным и находится в зоне высокого риска вспышки региональных войн, которые могут поставить под угрозу мир во всем мире и нанести непоправимый урон человечеству. Логика угроз, давления, санкций и войны по-прежнему является основой мышления американских политических и военных стратегов в Европе, стремящихся К достижению своих национальных интересов.

Под прикрытием «нормализации отношений» между Белградом и Приштиной НАТО стремится формализовать легализацию оккупации Косова и Метохии в глазах международной общественности. Таким образом, НАТО также станет формальной силой, которая решает все в лжегосударстве Republika e Kosovës, и любая попытка защитить Сербией сербов в КосМете будет считаться «агрессией на Косово».

Ложное государство Republika e Kosovës станет американским «авианосцем» в дальнем походе НАТО на Восток. Если учитывать, что край Косово и Метохия является частью национальной территории Сербии, то и сама Сербия против воли народа вскоре, по существу, станет на сторону НАТО. О такой стратегии пакта НАТО должны думать сербские власти, сегодня и в будущем.

Самое важное - никогда не давать согласия и не подписывать какие бы то ни было соглашения на отделение края Косово и Метохия от Сербии в форме "обязывающего соглашения". Эта сербская Святая Земля является залогом прошлого и предков для будущих поколений.

\section{Отношение запада к ложному государству Косово и Метохия}

Европейский союз и НАТО не хотят, чтобы Сербия оставалась нейтральной в военном отношении. НАТО считает, что он достаточно силен, чтобы принуждать и шантажировать режимы оставшихся государств на Западных Балканах, вынуждая стать его членами. Стремится достигнуть этих целей без применения оружия. Не исключено, что в будущем НАТО сделает это через союз государств, которые традиционно враждебно относятся к Сербии и сербскому народу на Балканах 1 .

Никто не сможет отобрать у нас Косово, если мы сами не передадим его, и если мы его передадим, то инфраструктура США, Великобритании и НАТО начнет быстро строиться, что необходимо для проведения военных операций на юго-востоке Европы. Таким образом,

1 URL: http://www.paradoks.rs/strategija-natomini-repriza-ratova-na-balkanu/. 
Сербия станет государством на линии огня. Это достаточная причина, чтобы Сербия никогда не поддерживала возможности членства т.н. Republika e Kosovës в региональных и международных организациях и не давала согласия и не подписывалась под каким-либо «обязывающим соглашением». В этом суть всей кампании, проводимой США и Великобританией, под прикрытием разговоров об укреплении мира и безопасности на т.н. Западных Балканах.

Отдельные политические организации, НПО и отдельные бывшие политики и общественные деятели в Сербии настойчиво пытаются убедить людей в том, что «другого выхода нет» и что именно сейчас и в ближайшем будущем необходимо ради «лучших перспектив для потомства» решить кризис Косова и Метохии. Если перспектива заключается в сдаче национальной территории и перемещении и изменении международно признанных границ Сербии, то пусть они спросят тех, кому уже ясно, что это классический захват и оккупация исторической национальной территории. Подавляющее большинство людей считают, что речь идет о неконституционных действиях и продвижении позиции, неконституционной и противоречащей жизненно важным национальным интересам.

Американские, британские и немецкие инструкторы и советники годами организовывают, оснащают и обучают т.н. Косовские силы безопасности (КСБ) и готовят их взять на себя функции будущих Косовских вооруженных сил (КВС). Судя по динамике реализации стратегии США на Западных Балканах, пришло время формализовать политические, защитные и международные предпосылки усиления независимости ложного НАTO-государства Republika e Kosovës. Сроки даже были публично объявлены и пропагандируются в средствах массовой информации.

Чтобы окончательно завершить процесс формализации независимости лжегосударства Republika e Kosovës и продвигать оставшиеся государственные учреждения, такие как Косовские вооруженные силы, НАТО задействует все большие возможности. Для этого были использованы материальные, кадровые, организационные, международные и информационные ресурсы, которые должны легализовать <эту независимость> после т.н. «обязывающего соглашения», которое навсегда лишило бы права на Косово и Метохию сербский народ и будущие его поколения, поскольку граница с Кошаре и Паштрика была бы официально перенесена на Мердаре, Преполац и Яринье.

«НАТО поддерживает развитие Косовских сил безопасности в рамках мандата, на основе которого эти силы были сформированы, а если он будет изменен, Североатлантический альянс рассмотрит уровень своего участия В Косово", - говорится в сообщении HATO [1, URL].

Формирование т.н. «косовской армии» возможно на основании конституционных изменений, требующих двух третей <голосов «Ассамблеи Косова». - Прим. перев.>, то есть такой же поддержки со стороны депутатов, представляющих в парламенте «квоту меньшинств» [Там же $]^{1}$.

Вот уже в течение долгого времени и до сих пор подразделения Косовских сил безопасности выполняли задачи вместе с патрулями KFOR. Нечто подобное Сербия уже пережила во время Второй мировой войны - после разрушения государства.

В деле уничтожения сербских национальных интересов британцы показали

1 Это невозможно до тех пор, пока против будут выступать депутаты парламента от «Сербского списка». «Парламент Косова» состоит из 120 мест. 100 депутатов избираются голосованием, 20 - по квоте меньшинств. Из этих 20 «Сербский список» составляет 10 мест, что позволяет сербским депутатам блокировать изменения в законодательстве - на уровне той части парламента, которую составляет «квота меньшинств». - Прим. перев. 
себя неприятелями сербского народа и государства Сербии. Обо всех шагах, предпринятых НАТО с властями лжегосударства Republika e Kosovës, власть Сербии имела полную информацию, но, к сожалению, она не действовала открыто и не направляла протест или несогласие. Не было твердого настаивания на этом. И все из-за боязни «обидеть" ведущих членов НАТО и вызвать их гнев.

Сербия даже не опротестовала факт организации обучения будущих офицеров, сержантов и солдат, символически предупредив сербов о том, что коллаборация в Косовских силах безопасности является уголовным преступлением. Это можно было сделать, используя легальные методы - через сербские политические партии КосМета и через правовые институции и суды Республики Сербии. К сожалению, этого не произошло. Даже сербские партийные активисты часто присутствовали на торжествах, где перед тачи провозглашались присяги лжегосударству Republika e Kosovës. Люди в Сербии по большей части не знают этого.

Сербия может оказаться в ситуации, когда после подписания т.н. обязывающего соглашения на административной линии южной провинции окажутся вооруженные силы Republika e Kosovës, как часть структуры НАТО. Это сюрприз для неучей-политиков и их платных аналитиков, которые повторяют полученные с Запада мантры.

В НАТО знают, что без окончательной формализации независимости лжегосударства Republika e Kosovës нельзя юридически продвигать КОС без отмены Кумановского соглашения, Резолюции 1244 Совбеза ООН и если сербы в косовском парламенте не поддержат голосование за формирование будущей армии. Тем не менее всем ясно, что НАТО в одностороннем порядке бомбит и оккупирует народы и государства, и почему бы им во имя продвижения сво- их интересов не нарушить в том числе и другие положения международного и национального права.

В то же время у администрации США есть намерение посредством включения лжегосударства Republika e Kosovës в НАTO после «обязывающего соглашения» охватить большую часть региона Западных Балкан, что будет дополнительным рычагом воздействия на Сербию, принуждаемую присоединиться к Альянсу. Параллельно политическим, экономическим и энергетическим процессам он намерен полностью вытеснить любое присутствие России на Балканах и избавиться от «русской угрозы", которая эксплуатируется посредством пропаганды СМИ.

Действия ряда политических партий, НКО и многих «первых кнопок» национальных СМИ готовят общественность Сербии к тому, что речь идет именно о «цене европейского пути» Сербии, о ее развитии и «светлых европейских перспективах», которым нет альтернативы. Эта пропаганда длится уже долгое время, поэтому сегодня в Сербии без стыда открыто требуют капитуляции и предательства Косова и Метохии. К сожалению, некоторые шантажированные политики все чаще воспринимают это как необходимость, и вся проблема для них сводится к тому, как «убедить народ".

Таким образом, на сцене неприкрыто антиконституционная деятельность многих субъектов и отдельных лиц в Сербии, которые почти систематически распространяют пораженческие настроения по вопросу самой возможности сохранения Косово и Метохии в составе Сербии. Никто еще не был привлечен к судебному процессу за незаконные действия и за совершенное уголовное преступление по разрушению территориальной целостности, суверенитета и неприкосновенности Республики Сербии.

Запад планировал вложить еще больше финансовых средств в пропа- 
ганду СМИ, работу неправительственных организаций, политических партий и отдельных лиц, которые готовы в Сербии продвигать идеи зависимости судьбы народа и государства от отношения к НАТО, в первую очередь к США. Народу косвенно угрожают тем, что реакцией на упорство в отстаивании суверенитета Сербии станет новая волна насилия албанцев в КосМете или введение санкций Запада. Сербский народ не должен заставлять себя действовать нерационально и спокойно принять нарушение Конституции и предательство Косово и Метохии.

\section{Великоалбанские претензии как проблема решения Косметского кризиса}

Национальное пробуждение албанцев, начавшееся еще в эпоху Османской империи, также одной из целей ставило намерение постепенно объединить территории, на которые был привлечен албанский народ оккупационными властями. Из-за преданности и верности албанцев по отношению к Османской империи они поощрялись властями увеличением жизненного пространства - за счет подавления и притеснения соседних народов. Пространство Македонии, южной Сербии, Косово и Метохии и Черногории частично обезлюдело вследствие того, что сербское население краев, испытывая на себе мстительность турок, вынуждено было покидать родные очаги, опустошавшиеся, неоднократно подвергавшиеся мстительным походам турок. В свою очередь, албанцы постепенно заселяли плодородные долины. Теперь же они намеревались формализовать объединение этих территорий под своим контролем.

Призренская лига была основана 10 июня 1878 года с целью объединения всех албанцев в один большой албанский вилайет, который территориально объединил бы четыре вилай- ета, в которых тогда жили албанцы: Битолийский, Косовский, Янинский и Скадарский. Было запрошено право на автономию в рамках Османской империи. Вторая албанская лига была основана во время немецкой оккупации в 1943 году, а третья - в 1946 году в Нью-Йорке.

Все три лиги осуществляли деятельность под эгидой великих имперских держав: Османской империи, нацистской Германии - и вплоть до HATO и ЕС.

Любая попытка создать Великую Албанию, которая - согласно планам в дополнение к уже существующему албанскому государству собирается включать сербское Косово и Метохию, Прешево и Бужановац, восточные районы Черногории (Плав и Гусинье, Тузы, Улцинь, вплоть до Бара), западную часть нынешней Македонии, включая и Куманово, и северо-западную часть Греции, - приведет к хаосу на Балканах и дестабилизации Европы. Подобно тому, как распад бывшей СФРЮ не произошел бы без детонатора - губительных межнациональныхи религиозныхвойн, любая попытка практического воплощения идей «Великой Албании» была бы прелюдией к еще более кровавой этнической войне в центральной части Балкан [2. - С. 10-16].

Потеря национального стержня и исторического ядра державной территории приведет сербов к великим и страшным искушениям. Они рассматривали бы Косово и Метохию только как временно оккупированные территории, которые рано или поздно необходимо было бы вернуть. Любой ценой. Следовательно, между Сербией и этой новой «Великой Албанией» будет установлено постоянное состояние ожидания потенциального вооруженного столкновения, которое может в любой момент превратиться в войну. Фактическое открытие границ под прикрытием слов о т.н. Открытых Балканах не может залечить раны 
Косово и Метохии и не остановит по существу попыток построения т.н. Великой Албании.

Реализация проекта «Великой Албании" и последствия, которые она неизбежно вызовет, поставит под угрозу жизненно важные интересы ЕС и, следовательно, всю систему европейской интеграции. С другой стороны, это позволило бы проникнуть исламскому фундаментализму в Косово и Метохию, Черногорию, Федерацию БиГ и Западную Македонию [2. - С. 16-20].

НАТО в Сербии постоянно пропагандирует в СМИ некие новые ценности, которые обычный народ давно признал ложью никчемной и некомпетентной, устаревшей пропагандистской машины, которая тратит огромные деньги налогоплательщиков.

Прозападные лоббисты в Сербии, политики и отдельные общественные деятели постоянно повторяют одну и ту же фразу, как какую-то набившую оскомину мантру. Постоянно говорят о «западных и европейских ценностях", причем это бесконечное повторение иногда начинает звучать уже просто как карикатура и дешевая пропаганда, которая более не прикрывает откровенную ложь. НАТО было бы лучше, если бы его не продвигали такие политики и общественные деятели, страшно далекие от своего народа. Люди им больше не доверяют, даже тогда, когда они говорят какую-никакую правду.

В то же время часть неудачливых политиков выступает в качестве тех, кто продвигает «российские интересы» в Сербии, а в сущности, защищает свои личные интересы посредством обязательного участия в правительстве ради защиты собственных привилегий и малой группы окружающих их людей. И они очень вредны для сербских национальных интересов, потому что они и не укрепляют политические партии, которыми управляют, и не пользуются широкой народной поддержкой из-за своей некомпетентности и корысто- любия. Это не способствует развитию сербско-российских отношений и не содействует налаживанию сотрудничества. Сербский народ пытается сохранить исконные, традиционные ценности и противостоять насилию НАТО, прежде всего США и Великобритании, но без более сильной поддержки России и Китая будет трудно противостоять этому давлению.

Сравнивая отношение т.н. «международного сообщества» к Республике Сербской (Боснии и Герцеговине) и к лжегосударству Republika e Kosovës, член Президиума БиГ (от сербов) Милорад Додик обратил внимание на проблему двойных стандартов и заявил: "Они отнимают Косово у Сербии, нас вталкивают в несостоятельную БиГ, а затем говорят, что нет никаких изменений границы. Конечно, это нужно оставить истории и времени, на данный момент кажется, что изменений нет. И не прошу насильственно менять границы, но через соглашение международами. И констелляция отношений изменится, мир не такой, как десять лет назад, мы увидим, что будет в течение следующих десяти» [3, URL].

Заявления чиновников в регионе о Косове и Метохии часто ясно говорят об их предвзятости. Согласно пресс-релизу премьер-министр Албании Эди Рама заявил, что Албания и "Косово»намерены убрать границы, Дуррес скоро станет де-факто «косовским» портом, а посредством проекта «мини-Шенген» можно добиться того, что Сербия признает «Косово». На заседании правительств Тираны и Приштины было подписано 14 соглашений и меморандумов и согласовано совместное отмечание 150-летней годовщины Призренской лиги, а также завершение всех технических деталей для создания межгосударственного фонда финансовой поддержки «Прешевской долины», что выдвигает на первый план нынешнюю идею проекта «Великой Албании».

Премьер-министр Албании Эди Рама также заявил, что проект «Открытые 
Балканы» повлияет на улучшение жизни в регионе и что необходимо приложить усилия «для большего признания Косово Сербией»: "Это может быть достигнуто только с помощью дипломатии и мудрости, терпения и способности выиграть битву, подобную дипломатичной, а не военной, когда Косово победило. Свобода и государственность не могут быть подвергнуты сомнению или отменены, и они принадлежат "Косову" и нам в Албании».

Эти слова не нуждаются в особом комментарии. Каждое свободное государство выразило бы протест и довело бы до сведения международных субъектов, что Албания вмешивается во внутренние дела Сербии. Власть в Сербии как будто не видит этого, напротив, принимает стратегические меры в строительстве инфраструктуры автомагистрали и железной дороги, а также в открытии границ ради ускорения реализации проекта «Великой Албании».

Проект «Великой Албании» - это объявление о крупном бедствии, разрушении и разорении государств и наций на Балканах. Сербия должна остановить становление «Великой Албании" путем сохранения Косово и Метохии в своем составе и предотвратить изменение границ. То, что Запад позволяет албанцам, нельзя запретить и сербам. Международное право и резолюция Совбеза ООН 1244 - на стороне Сербии.

Профессор, д-р Радослав Гачинович, старший научный сотрудник Института политических исследований, рассказывает «Новостям», что взаимодействие органов власти Албании и т.н. Republika e Kosovës представляет собой род давления на ЕС и на других переговорщиков в диалоге между Белградом и Приштиной: Албания в конце XX века уступила свою территорию для подготовки террористов, которые затем перебрасывались на территорию Сербии. Такая агрессия продолжалась мирными, психологическими и пропа- гандистскими средствами, влияющими на людей из Сербии и на международное сообщество. Это казалось скрытым, а теперь предупреждения становятся все более открытыми, и очень опасно молчание международного сообщества, на глазах которого создается почва для «Великой Албании» [4, URL].

Микеле Ризи, бывший командир миротворческой миссии НАТО в Косово и Метохии (КФОР), своим заявлением о том, что формирование Объединения сербских общин несет в себе риск «боснизации» Republika e Kosovës, что может «угрожать государственному энтитету Republika e Kosovës", встал на сторону Приштины и нарушил Резолюцию 1244. Ризи изложил это на конференции Фонда Оборонного колледжа НАТО в Риме, с дополнительной оценкой, что «формирование Объединения сербских общин является спорным вопросом в Брюссельском соглашении» [5, URL].

Албанцы считают, что они стратегически обрели территорию и создали предпосылки, чтобы в благоприятный момент отделить эту часть государства и присоединить к т.н. «Великой Албании». Конечно, это только их оценка, ибо сделать это будет не так просто, поскольку они поставили под угрозу суверенитет соседних государств. При неблагоприятном развитии ситуации Албания и албанский народ рискуют спровоцировать соседние государства и исчезнуть как отдельное государство. Албания не имеет ни военной, ни экономической мощи для поддержки реализации этого великоалбанского проекта. Она рассчитывает на открытую, долговременную и сильную поддержку НАТО. Есть государства, которые молчаливо поддерживают этот проект, в первую очередь те, которые находятся под влиянием глобалистов и некоторых старых великодержавных проектов и интересов на Балканах. Прежде всего, это касается Германии, Турции и теперь США, после прихода Байдена к власти.

Сегодня сербский народ в КосМете сохраняет веру в то, что он не будет 
оставлен и предан властями своей державы. Сербии. В то же время албанские экстремисты сдерживаются, потому что знают, что КосМет вернется под суверенитет Сербии. Если бы власть в Сербии подписала т.н. «обязывающее соглашение», некуда было бы возвращаться 220000 перемещенных и изгнанных сербов, продолжился бы дальнейший исход изгнанных, а на административной линии, отделяющей южную провинцию, расположились бы Косовские вооруженные силы, как часть структуры НАТО. Это было бы неожиданностью для некоторых никчемных политиков и их платных аналитиков, которые повторяют западные мантры о примирении народов и процветании государств на т.н. Западных Балканах.

Премьер-министр Албании Эди Рама заявил, что Косово и Албания намерены «убрать границы», а также что албанская гавань Дуррес скоро станет де-факто «косовской». Об этом он заявил в начале совместного заседания албанского и косовского правительств, которое проходило во Дворце конгрессов в Тиране 2 октября 2020 года. "Соглашение, которое мы вскоре подпишем для содействия таможенным процедурам между двумя странами, приводит нас де-факто к превращению порта Дуррес в порт Косово», - сказал Рама. Не упоминает Рама ни о Сербии, ни о ее интересах, а власть в Сербии просто остается слепой и морочит народ лозунгами о мире, процветании и «счастливом будущем». Шестая совместная сессия двух правительств состоялась под лозунгом «Вместе без границ", и в делегации, которая отправилась в Тирану, не было министров Сербского списка. На заседании правительств Албании и т.н. Косово, на котором было подписано в общей сложности 14 соглашений и меморандумов, были согласованы совместное проведение мероприятий, связанных со 150-й годовщиной Призренской лиги, а также все технические детали для установления межгосударственного фонда поддержки «Прешевской долины».

После встречи были подписаны три особо важных соглашения: о таможне в Дурресе, о железнодорожной линии и о гидроэлектростанции для Косово, которая будет сооружена в Албании. И по этому видно, что речь идет о единой стратегии интеграции Албании и лжегосударства Republika e Kosovës. Сербия по-прежнему молчит и не имеет официальной реакции, а слепо следует по пути т.н. «Открытых Балкан».

Албин Курти, как и предыдущие т.н. «президенты лжегосударства Republika e Kosovës», постоянно выражает свою ненависть к Сербии и намерение объединить Косово с Албанией в процессе создания т.н. Великой Албании. Он указывает: «Были подписаны вредные для Косово соглашения, которые даже Конституционный суд, каким бы он ни был, не смог проглотить. В этом смысле нам нужна новая глава, нам нужен новый подход, и для нас это должно быть принципиально, когда граждане являются победителями с прочным признанием в центре. В последнее время произошел тектонический сдвиг в лучшую сторону, поскольку в последнее десятилетие считалось, что Косово идет на уступки, чтобы в конечном итоге получить признание от Сербии». Курти подчеркнул, что взаимное признание является стержнем соглашения, и все друзья и партнеры Косово говорят об этом [6, URL].

Такие действия Албании и лжегосударства Косово открыто враждебны Сербии. Печально, что власть Сербии не замечает этого, как будто ничего не происходит. Власть в Сербии озвучивает пустые фразы о добрососедстве, мире и сотрудничестве, в то время как албанские экстремисты из Албании и КосМета похищают у нас перед глазами эту святую землю. Удивительно молчание властей Сербии... Не реагируют, не предупреждают EC, НATO и ООН о том, что у всех у них 
на глазах и с их помощью реализуется проект т.н. Великой Албании. Проект, который имеет исторический контекст, преемственность и актуальность наряду с явно выраженной тенденцией осуществления великодержавного Исламского проекта в духе т.н. Призренской лиги.

Международное право и резолюция Совбеза ООН 1244 на стороне Сербии. Поэтому своим молчанием власти Сербии рискуют разжечь недовольство, следствием которого могут стать акции массового протеста с непредсказуемыми результатами. Народ в Сербии молчит, но уж точно не поддерживает проект т.н. «Открытых Балкан", как проект США, выстраиваемый на руинах многострадального оккупированного края Косово и Метохии.

\section{Сербские заблуждения относительно решения Косметского кризиса}

Большое счастье сербского народа заключается в том, что люди думают не так, как отдельные политические лидеры, НКО или те общественные деятели, которые действуют неконституционно.

Косово никто не может отнять у нас, если мы не передадим его сами. Это достаточная причина, чтобы Сербия никогда не принимала возможности включения т.н. Косово в региональные и международные организации.

Власти Сербии настойчиво пытаются убедить людей в том, что другого выхода нет и что именно сейчас и очень скоро Косовско-Метохийский кризис должен быть завершен ради «перспективы потомства». Если перспектива заключается в сдаче национальной территории и перемещении и изменении международно признанных границ Сербии, то пусть они спросят людей, тех, кому уже ясно, что это классический захват исторической национальной территории, а также неконституционные действия и подписание соглашений, которые не соответствуют праву и воле народа.

Развитие русофобии в Сербии является частью подготовки Запада к окончательному разрешению статуса лжегосударства Republika e Kosovës. Препятствуя интересам Китая и России в Сербии и на Балканах, США, НАТО и ЕС стремятся убить их волю к борьбе за выживание КосМета в составе Сербии

Как в каком-то кошмарном сне, Республика Сербия и символически, и по сути постепенно теряет атрибуты свободного, суверенного и независимого государства при разрешении КосовскоМетохийского кризиса. Параллельно с этим процессом Сербия полностью, помимо воли народа, втягивается в евроатлантические структуры, что согласуется с интересами Запада. Такое неразумное поведение ничем не может быть оправдано.

Ведя переговоры под эгидой США и EC, власть Сербии, в ущерб сербскому народу, стала на сторону государств, которые создали и в большинстве своем признали лжегосударство Republika e Kosovës. Таким образом, исключены другие крупные державы и государства, которые были на стороне Сербии и сохраняли ее суверенитет и территориальную целостность в международных учреждениях. Речь о таких, как Россия, Китай, Индия, Бразилия, Испания, Греция, Словакия, Румыния и многие другие страны мира. Большой вопрос: почему власти Сербии не приглашают Китай и Россию участвовать в переговорном процессе, дабы урегулирование кризиса продолжалось под эгидой ООН?

Для политиков лучше отказаться от шантажа Запада и «материальных аргументов» в пользу лучшей жизни, потому что люди не понимают их и не поверят им. Этими словами они признают свою зависимость, унижение и предательство национальных интересов. 
Никто не может узурпировать право народа на его стратегические решения.

Если бы сербский народ на протяжении всей истории руководствовался только логикой "лучшей жизни" и забывал о вере и духовных ценностях, сегодня, вероятно, не было бы и самой Сербии. Этот холопский и подданнический характер отдельных общественных деятелей и организаций не соответствует сербскому народному духу.

\section{Заключение}

Признание независимости Косово было и остается «основным условием вступления Сербии в ЕС», и нынешняя власть в Сербии продолжает постоянно говорить, как и в прошлом, что она «не видит другого пути для Сербии, кроме пути в ЕС", и что у ЕС нет альтернативы. Это самоубийственный инстинкт порочной и легкомысленной квазиполитической элиты в Сербии. Все эти партии не представляют воли народа, но находятся под мощным влиянием ведущих государств Запада и получают огромное финансирование для своего продвижения в средствах массовой информации и для компрометации национальных партий и движений, которые борются за защиту жизненно важных национальных интересов.

Америке и ведущим странам НАТО теперь, после 22 лет с момента оккупации этой части Сербии, нужна легитимно оформленная «купчая на недвижимость», чтобы постоянно удерживать Косово под своим контролем. Американцы и англичане борются не ради счастья и демократии "косоваров», а во имя долгосрочных интересов: дешевого базирования и строительства военной инфраструктуры в Юго-Восточной Европе, на центральной позиции, перекрестке цивилизаций, религий, и места, через которое осуществляется незаконный оборот наркотиков. По этим причинам они не хотят допустить того, чтобы границы Сербии оставались неизменными и чтобы проблема Косовско-Метохийского кризиса решалась демократическим путем: реализацией прав в соответствии с самыми высокими международными стандартами.

Сербы не должны удивляться сегодня всему, что происходит с нами в Косово и Метохии, поскольку пожинают плоды действий властей в рамках ошибочных брюссельских переговоров, которые велись вне ООН, часто вопреки Конституции Республики Сербии. Настало время прекратить разрушительную политику неконституционных действий, приводящих к постепенному признанию отделения и оккупации Косово и Метохии.

Албанцы должны знать, что лжегосударство Republika e Kosovës долго не протянет, и вопрос обстоятельств и времени, когда все это будет кончено и сербский флаг снова будет реять на Шаре и Проклетии. Косово и Метохия в соответствии с Конституцией Сербии являются частью сербского государства, что подтверждается резолюцией 1244 Совета Безопасности ООН. Сербия должна сделать все, чтобы вернуть процесс переговоров под прикрытием ООН согласно с резолюцией 1244 СБ ООН. В соответствии с этим, необходимо включить в состав сил КФОР вооруженные силы других государств, не входящих в НАТО.

Недопустимо дальнейшее ползучее выполнение поручений и требований НАTO, разрушающих жизненно важные сербские национальные интересы. Это ложная дилемма: «должны ли мы жить для наших дедов или для наших внуков?», также как и «Небесная Сербия или будущее». Сербии нужно и одно, и другое: почитание предков и достоинство потомков. Без чести и гордости за своих предков нет будущего.

Вот что говорил по поводу необходимости сохранения Косово и Метохии на литиях по случаю защиты святынь в Черногории блаженнопочивший митрополит Амфилохий (Радович): «И пока мы живы, и пока будет жив хоть 
один потомок сербского народа будем говорить: Косово - зеница нашего ока, Косово - сердчевина нашего сердча, Косово - наш святой град Иерусалим, и мы не можем отречься om него, как не можем отречься от души своей и судьбы своей ни в земной жизни, ни в Божьей вечности».

Идея т.н. Великой Албании должна исчезнуть в Косове и Метохии, а не подпитываться формированием и

признанием лжегосударства Republika e Kosovës. Это завет предков для будущих поколений.

\section{Литература}

1. НАTO подржава развој Косовских снага безбедности! - URL: http://www.pravda. rs/2018/5/4/nato-podrzava-razvoj-kosovskih-snaga-bezbednosti/ (дата обращения: 29.11.2021).

2. Група аутора. Припрема и извођење противтерористичких дејстава на Косову и Метохији 1998 године. - Београд: Институт ратне вештине, ГШ ВСЦГ, 1998. - С. 10-20.

3. Додик: Отму Косово, па причају да нема промена границе! — URL: http://www.pravda. rs/2018/6/3/dodik-otmu-kosovo-pa-pricaju-da-nema-promena-granice/ (дата обращения: 29.11.2021).

4. ČETIRI TEMELJA ZA «VELIKU ALBANIJU»: Vlade iz Prištine i Tirane na zajedničkoj sednici potvrdile opasan plan. — URL: https://www.novosti.rs/vesti/politika/922636/cetiri-temeljaveliku-albaniju-vlade-pristine-tirane-zajednickoj-sednici-potvrdile-opasan-plan (дата обращения: 29.11.2021).

5. HATO се грубо умешао у статус Косова. - URL: https://rs.sputniknews.com/ analize/202010011123495552-nato-se-grubo-umesao-u-status-kosova-/ (дата обращения: 29.11.2021).

6. Курти фантазира: Србија као Русија - од Српске прави Белорусију, а од Црне Горе Украјину. — URL: https://rs.sputniknews.com/20211122/kurti-fantazira-srbija-kao-rusija--od-srpske-pravi-belorusiju-a-od-crne-gore---ukrajinu--1131802696.html (дата обращения: 29.11.2021).

Перевод статьи с сербского на русский осуществил Павел Вячеславович Тихомиров, помощник главного редактора Информационной службы «Русская народная линия», автор книг и статей по балканской тематике, член Международной комиссии по установлению правды о системе концентрационных лагерей Ясеновац

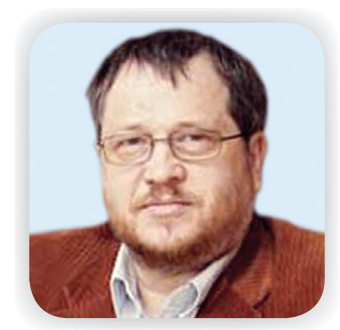

